\title{
Changes in Plant Species during Succession in a Sago Forest
}

\author{
Yoshimasa Kumekawa1,2*, Matheus Kilmaskossu33, Makito Mori², Akira Miyazaki², \\ Katsura Ito2, Ryo Arakawa2, Tatsuya Fukuda², Hubertus Matanubun ${ }^{3}$, \\ Yoshinori Yamamoto \\ ${ }^{1}$ The United Graduate School of Agricultural Science, Ehime University, \\ Kochi, Japan \\ ${ }^{2}$ Faculty of Agriculture, Kochi University, Kochi, Japan \\ ${ }^{3}$ Papua State University, Manokwari, Indonesia \\ Email: inganock@yahoo.co.jp
}

Received 24 September 2014; revised 23 October 2014; accepted 6 November 2014

Copyright (C) 2014 by authors and Scientific Research Publishing Inc.

This work is licensed under the Creative Commons Attribution International License (CC BY).

http://creativecommons.org/licenses/by/4.0/

(c) $\underset{\mathrm{EY}}{\mathrm{EY}}$ Open Access

\section{Abstract}

The variation in solar environments during succession in sago forests is thought to affect the growth of many plant species. To clarify the pattern of plant colonization in sago forests at various successional stages, we constructed eleven $10 \mathrm{~m} \times 10 \mathrm{~m}$ quadrats in different solar conditions in sago forests, measured and calculated the relative illumination intensity, collected all plant species in these quadrats, and used two chloroplast gene sequences-the rbcL gene of ferns and the $\operatorname{trn} L$ intron of angiosperms to molecularly identify them. The number of ferns increased while the number of herbaceous species decreased during the process of succession. Moreover, the number of woody species was not significantly correlated with the relative light intensity. Based on these results, it can be concluded that woody species colonized and grew at various successional stages but herbaceous species and ferns did the same in the early and late successional stages, respectively, in the sago forest.

\section{Keywords}

Chloroplast DNA (cpDNA), Plant Species, Sago Palm

\section{Introduction}

Secondary succession tends to happen in various places and it can also start very rapidly at places where the ex-

\footnotetext{
*Corresponding author.
}

How to cite this paper: Kumekawa, Y., Kilmaskossu, M., Mori, M., Miyazaki, A., Ito, K., Arakawa, R., Fukuda, T., Matanubun, H. and Yamamoto, Y. (2014) Changes in Plant Species during Succession in a Sago Forest. American Journal of Plant Sciences, 5, 3526-3534. http://dx.doi.org/10.4236/ajps.2014.524369 
isting community is completely destroyed by environmental or artificial factors [1]. Some studies have described secondary succession in tropical forests [2]-[11]. One type of tropical forest, the sago forest, occurs in various areas of Indonesia such as lowlands, coastal regions, and river deltas. Many Indonesian sago forests were destroyed because of governmental development projects; however, rubber and oil palm plantations have been expanded recently through commercial sago extraction, because the sago palm Metroxylon sagu Rottb. (Arecaceae) plays an important economic and cultural role in Indonesia [12]. Therefore, it is thought that most sago forests have begun secondary succession in many areas of Indonesia. It is uncertain how the destroyed sago palm forest could be restored in Indonesia.

Old-growth forests can represent an important source of information to understand the processes that drive successional pathways, and plant mortality is a key element of forest dynamics that strongly influence the biological and structural diversity of forest ecosystems [13]. Previous study of the sago palm forest was described the colonization pattern of plant species in sago forests after their development by comparing floras from different successional stages by using DNA barcoding [14], a technique for characterizing the species of organisms, by using a short DNA sequence from a standard and agreed-upon position in the genome, which is very short compared to the entire genome, to identify an unknown sample in terms of a pre-existing classification [15] [16]. This study hypothesized that the numbers of species of ferns, Poaceae, and Cyperaceae colonizing a sago forest were correlated with the amount of solar radiation there, and therefore, their variation would be a clue to determine the forest's successional stage, but because no analyses of solar radiation had been made so far, it remains unclear whether the hypothesis is reasonable. Here, we analysed correlations between the numbers of species of ferns, Poaceae, and Cyperaceae and the measured solar radiation in sago forests in different successional stages in order to verify the previous hypothesis of [14].

\section{Materials and Methods}

\subsection{Plant Materials}

The plant materials were from one area of sago palm forests in the Malay Archipelago from March 2014. Figure 1 shows the location of the collection area used in this study. In this area, we selected four localities, A, B, C, and $\mathrm{D}$, and constructed 11 quadrats (four in $\mathrm{A}$, three in $\mathrm{B}$, one in $\mathrm{C}$ and three in $\mathrm{D}$ ) of $10 \mathrm{~m} \times 10 \mathrm{~m}$ and then collected all plant species from them.

\subsection{Measurement of Solar Radiation}

In order to clarify the illumination intensity in each quadrat, we averaged values obtained from three illuminometers (T-10A: Konica Minolta, Tokyo, Japan) in each quadrat and the control area. These values were of the

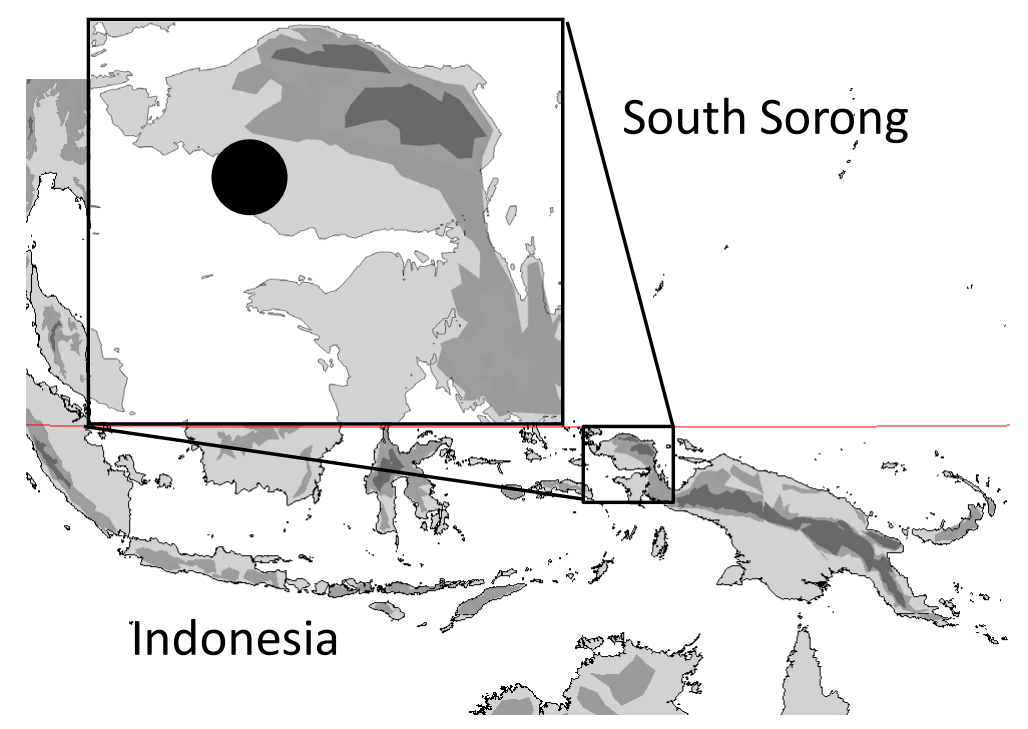

Figure 1. Sampling area of this study. 
absolute illumination intensity. We calculated the relative illumination intensity, which was the ratio of the absolute illumination intensity from each quadrat to the value from the control area. These measurements were carried out in just 12 locations, once in each quadrat and in the control area.

\subsection{DNA Analyses}

Total DNA was isolated from approximately 200 - 300 mg of an air-dried leaf with a Plant Genomic DNA Mini Kit (VIOGENE, Sunnyvale, USA), according to the manufacturers' protocol. Isolated DNA was resuspended in Tris-EDTA (TE) buffer and stored at $-20^{\circ} \mathrm{C}$ until use. DNA amplification by polymerase chain reaction

(PCR) was carried out in a $50-\mu \mathrm{L}$ reaction volume containing approximately $50 \mathrm{ng}$ total DNA, $10 \mathrm{mM}$ Tris$\mathrm{HCl}$ buffer (pH 8.3) with $50 \mathrm{mM} \mathrm{KCl}$ and $1.5 \mathrm{mM} \mathrm{MgCl}_{2}, 0.2 \mathrm{mM}$ of each dNTP, $1.25 \mathrm{U}$ Taq DNA polymerase (TOYOBO), and $0.5 \mu \mathrm{M}$ of each primer. We used the following thermal cycle profile for amplification: $40 \mathrm{cy}-$ cles of $1.5 \mathrm{~min}$ at $94^{\circ} \mathrm{C}, 2 \mathrm{~min}$ at $48^{\circ} \mathrm{C}$, and $3 \mathrm{~min}$ at $72^{\circ} \mathrm{C}$, followed by a final extension step of $15 \mathrm{~min}$ at $72^{\circ} \mathrm{C}$.

We amplified the $r b c L$ and $t r n L$ introns of cpDNA with primers designed by [17] [18], respectively. After amplification, the reaction products were run on a $1 \%$ agarose gel and digitally photographed.

We also confirmed the sequences of these regions. After amplification, the reaction mixtures were subjected to electrophoresis in $1 \%$ low-melting-temperature agarose gels for the purification of the amplified products. We sequenced the purified reaction products using a BigDye-terminator Cycle Sequencing Kit (Applied BioSystems) and a Model 3730A automated sequencer (Applied BioSystems) according to the manufacturer's instructions. For sequencing, we used the same primers as those used for amplification. Sequences for each region were pre-aligned with the CLUSTAL X program [19], and ambiguously aligned regions were manually corrected to minimise the number of indels. Alignment for all DNA regions required the inclusion of several indels.

Samples that were identical to a previously published sequence of the DNA Data Bank of Japan (DDBJ) were provided the species name from the previous publication. If samples did not have sequences identical to previously published ones, then a phylogenetic tree was constructed using our sequences and highly similar ones based on a homological search of the DDBJ. These samples were assigned the genus name of the plant species of the sister group of the sample in the phylogenetic tree. For example, when two sequences of our result were the sister group to the species of Stenochlaena (Blechnaceae), they were named after Stenochlaena sp. 1 and Stenochlaena sp. 2 (Table 1).

\section{Results and Discussion}

DNA barcodes are used to identify unknown species of flowering plants [20]. The use of chloroplast DNA (cpDNA) or nuclear DNA (nrDNA) sequences is appropriate for most species of plants because of the relatively fast mutation rate of these sequences [16], and some studies had shown a potential barcode [21]-[24]. Our results of DNA barcoding by using two cpDNA genes - the $r b c L$ gene and trnL intron of ferns and angiosperms, respectively, added to the morphological identifications and clarified that there were 66 species collected from 42 families in total (Table 1). Quadrat B1 had 21 species and was the most species of all quadrats, while only two species grew in quadrat A2, the least species (Table 1). Relative illumination intensity was measured to clarify the correlation between the number of species and the solar radiation. The results showed that the quadrat of $\mathrm{C}$ was the highest, B1 and D1 were relatively high, D2 and B2 were relatively low, and A1, A2, A3, A4, B3, and D3 were very low (Table 2). Although this result suggested that the brightest places did not necessarily have the most species, it suggested that the number of plants decreased in relatively dark places like A1, A2, A3, A4, B3, and D3 (Table 1 and Table 2).

Some studies had been reported the relationship between relative illuminance and plant species [25]-[27]. Previous study of the sago palm forest was hypothesized that the number of Poaceae and Cyperaceae increased in brighter environments [14]. Our results supported that the number of grass and sedge species had a significant correlation with the relative illumination intensity (Figure 2). To determine whether this situation was specialized only in Poaceae and Cyperaceae, we compared the numbers of all herbaceous species and the relative illumination intensity. The result was similar to those for Poaceae and Cyperaceae (Figure 3). Sago forest succession was considered to reduce solar radiation, and our results suggested that the number of herbaceous species, including Poaceae and Cyperaceae, decreased as sago forest succession progressed. However, why was the number of species not perfectly correlated with the progress of succession in the sago forest? One explanation is the number of ferns and woody species. Previous study of the sago palm forest was suggested that the number of 


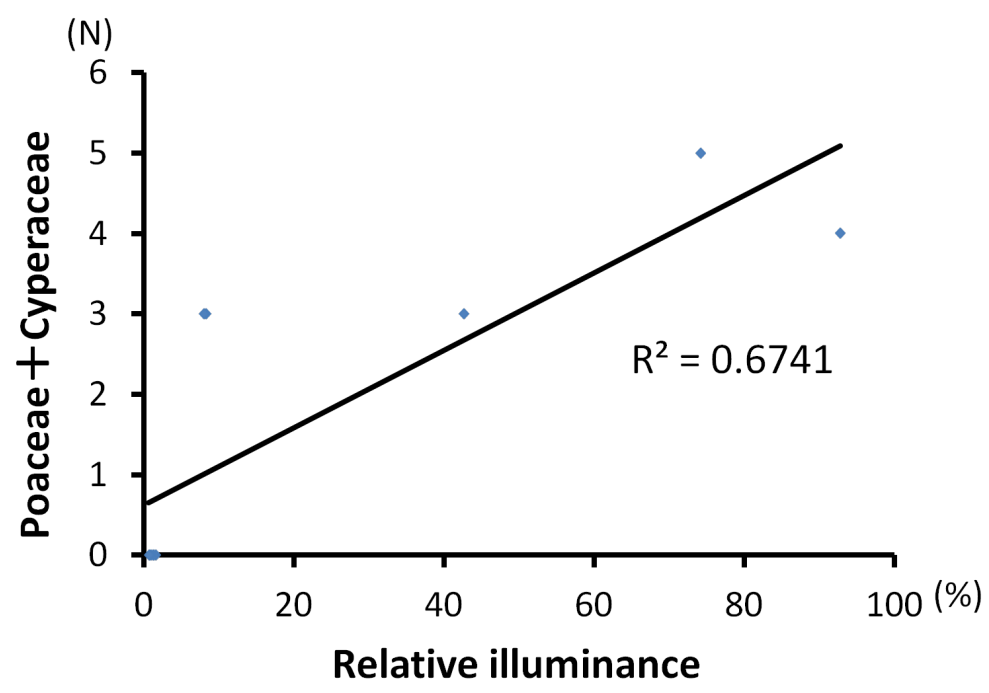

Figure 2. The correlation between the number of grasses and sedges (Poaceae and Cyperaceae) and the relative illumination intensity.

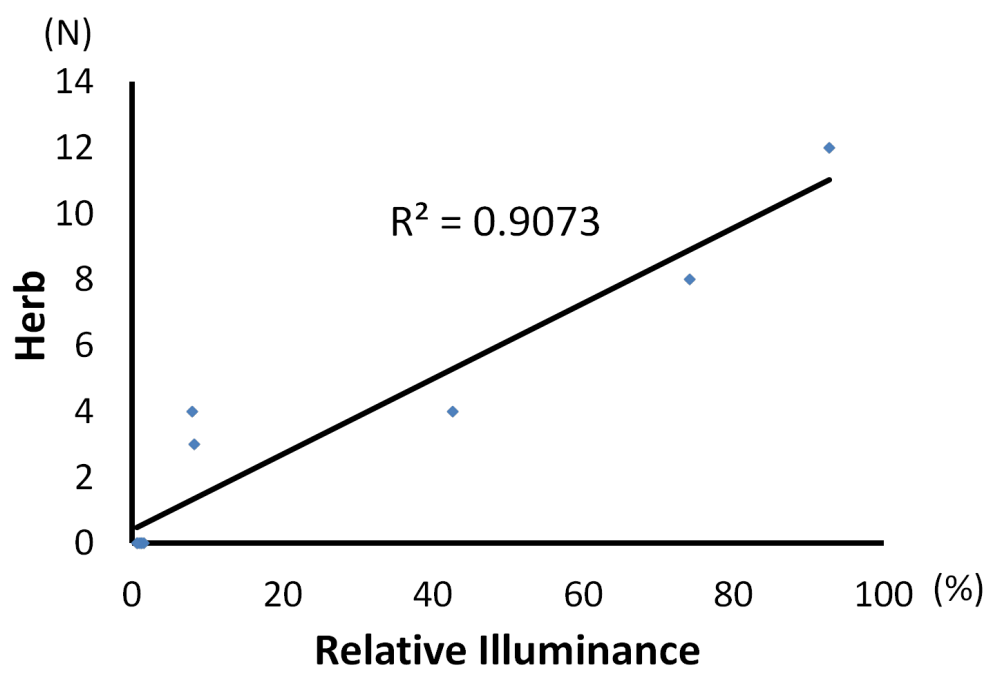

Figure 3. The correlation between the number of herbaceous plant species and the relative illumination intensity.

ferns increased in the dark environment of sago forests [14], and our results could support that suggestion (Figure 4). Moreover, our results indicated that the number of woody species had no significant correlation to the relative illumination intensity (Figure 5). After adding the numbers of ferns and woody species to those of herbaceous species, there was little correlation between the total number of plant species and the progress of succession in the sago forest. Woody species play a major role in creating terrestrial plant cover when conditions develop to the point where some bare ground and soil is present, and our results suggested that they colonized and grew at various successional stages, while herbaceous species and ferns did so at the early and late successional stages, respectively, of the sago forest.

There has been enormous growth in phylogenetic studies based on molecular data in recent years. In particular, the use of molecular markers has considerably improved our knowledge about past events shaping the genetic diversity within species [28]. The application of phylogenetic analysis is emerging as an important and practical tool for the study of native species and their relatives [29] [30]. Genetic information from native species has provided sources of useful traits for genetic hybridization between native and invasive alien species. Moreover, conscious efforts to search for desirable traits in plants have been underway for the past century, and 
Table 1. List of species, accession numbers, and quadrates. No accession number indicates identification by morphological characters. Taxonomic arrangement follows the Engler system. Black circles indicate the collected quadrates.

\begin{tabular}{|c|c|c|c|c|c|c|c|c|c|c|c|c|c|}
\hline \multirow{2}{*}{ Taxon } & \multirow{2}{*}{ Species } & \multirow{2}{*}{ Accession No. } & \multicolumn{11}{|c|}{ Quadrats } \\
\hline & & & A1 & A2 & A3 & A4 & B3 & D3 & B1 & B2 & D1 & D2 & $\mathrm{C}$ \\
\hline \multicolumn{14}{|l|}{ Pteridophyte } \\
\hline Aspleniaceae & Asplenium nidus & & & & & & & $\bullet$ & & & & & \\
\hline \multirow[t]{3}{*}{ Blechnaceae } & Blechnum orientale & AB981762 & & & & & & & $\bullet$ & & & & \\
\hline & Stenochlaena sp. 1 & AB981738 & $\bullet$ & & & & $\bullet$ & & $\bullet$ & $\bullet$ & & & \\
\hline & Stenochlaena sp. 2 & AB981745 & & & & & & & & & & & \\
\hline \multirow[t]{2}{*}{ Cyatheaceae } & Cyathea sp. & & & & & & & & & & & $\bullet$ & \\
\hline & Sphaeropteris glauca & AB981737 & & & & $\bullet$ & & & & & & & \\
\hline \multirow[t]{2}{*}{ Dennstaedtiaceae } & Histiopteris incisa & AB981764 & & & & & & & & $\bullet$ & & & \\
\hline & Pteridium aquilinum & & & & & & & & & & $\bullet$ & $\bullet$ & \\
\hline Equisetaceae & Equisetum debile & & & & & & & & & & & $\bullet$ & \\
\hline Gleicheniaceae & Dicranopteris linearis & AB981739 & & & & & & & $\bullet$ & $\bullet$ & $\bullet$ & & \\
\hline Hymenophyllaceae & Trichomanes javanica & & & & & & & & & & & $\bullet$ & \\
\hline Lycopodiaceae & Lycopodiella cernua & AB981757 & & & & & & & & & $\bullet$ & & \\
\hline Lygodiaceae & Lygodium microphyllum & AB981748 & & & & & & & $\bullet$ & $\bullet$ & & & \\
\hline \multirow[t]{3}{*}{ Oleandraceae } & Nephrolepis biserata & & & & & & & & & & & $\bullet$ & \\
\hline & Nephrolepis cordifolia & & & & & & $\bullet$ & & & & & $\bullet$ & \\
\hline & Nephrolepis sp. & & & & & & & & & & & $\bullet$ & \\
\hline \multirow[t]{5}{*}{ Pteridaceae } & Acrostichum aureum & & & & & & & & $\bullet$ & $\bullet$ & $\bullet$ & $\bullet$ & \\
\hline & Ceratopteris thalictroides & & & & & & & & & & & & $\bullet$ \\
\hline & Taenitis blechnoides & AB981766 & & & & $\bullet$ & & & & & & & \\
\hline & Trichomanes javanica & & & & & & & & & $\bullet$ & & & \\
\hline & Pityrogramma calomelanos & AB981780 & & & & & & & & & & & $\bullet$ \\
\hline Polyipodiaceae & Drynaria sparsisora & AB981754 & & & & & & $\bullet$ & & & & & \\
\hline Thelypteridaceae & Thelypteris sp. & LC000738 & & & & & & & & $\bullet$ & $\bullet$ & & \\
\hline \multicolumn{14}{|l|}{ Angiosperm } \\
\hline \multicolumn{14}{|l|}{ Monocotyledoneae } \\
\hline Araceae & Epipremnum рариапит & LC000733 & $\bullet$ & & & & & & & & & & \\
\hline \multirow[t]{5}{*}{ Cyperaceae } & Cyperus bifax & & & & & & & & & & & & $\bullet$ \\
\hline & Cyperus eragrostis & AB981770 & & & & & & & & & & & $\bullet$ \\
\hline & Fimbristylis dichotoma & AB981769 & & & & & & & & & & $\bullet$ & $\bullet$ \\
\hline & Fuirena umbellata & AB981755 & & & & & & & & $\bullet$ & $\bullet$ & & \\
\hline & Kyllinga brevifolia & AB981774 & & & & & & & & & & & $\bullet$ \\
\hline Limnocharitaceae & Limnocharis flava & & & & & & & & & & & & $\bullet$ \\
\hline Orchidaceae & Spathoglottis plicata & & & & & & & & $\bullet$ & $\bullet$ & & & \\
\hline \multirow[t]{2}{*}{ Pandanaceae } & Freycinetia sp. & AB981752 & & & & & & $\bullet$ & & & & & \\
\hline & Pandanus veitchii & AB981746 & & $\bullet$ & & & & & & & & & \\
\hline \multirow[t]{3}{*}{ Poaceae } & Axonopus sp. & AB981760 & & & & & & & & & & $\bullet$ & \\
\hline & Imperata cylindrica & & & & & & & & & $\bullet$ & $\bullet$ & & \\
\hline & Paspalum conjugatum & & & & & & & & & & $\bullet$ & & \\
\hline Pontederiaceae & Eichornia crassipes & & & & & & & & & & & & $\bullet$ \\
\hline
\end{tabular}




\section{Continued}

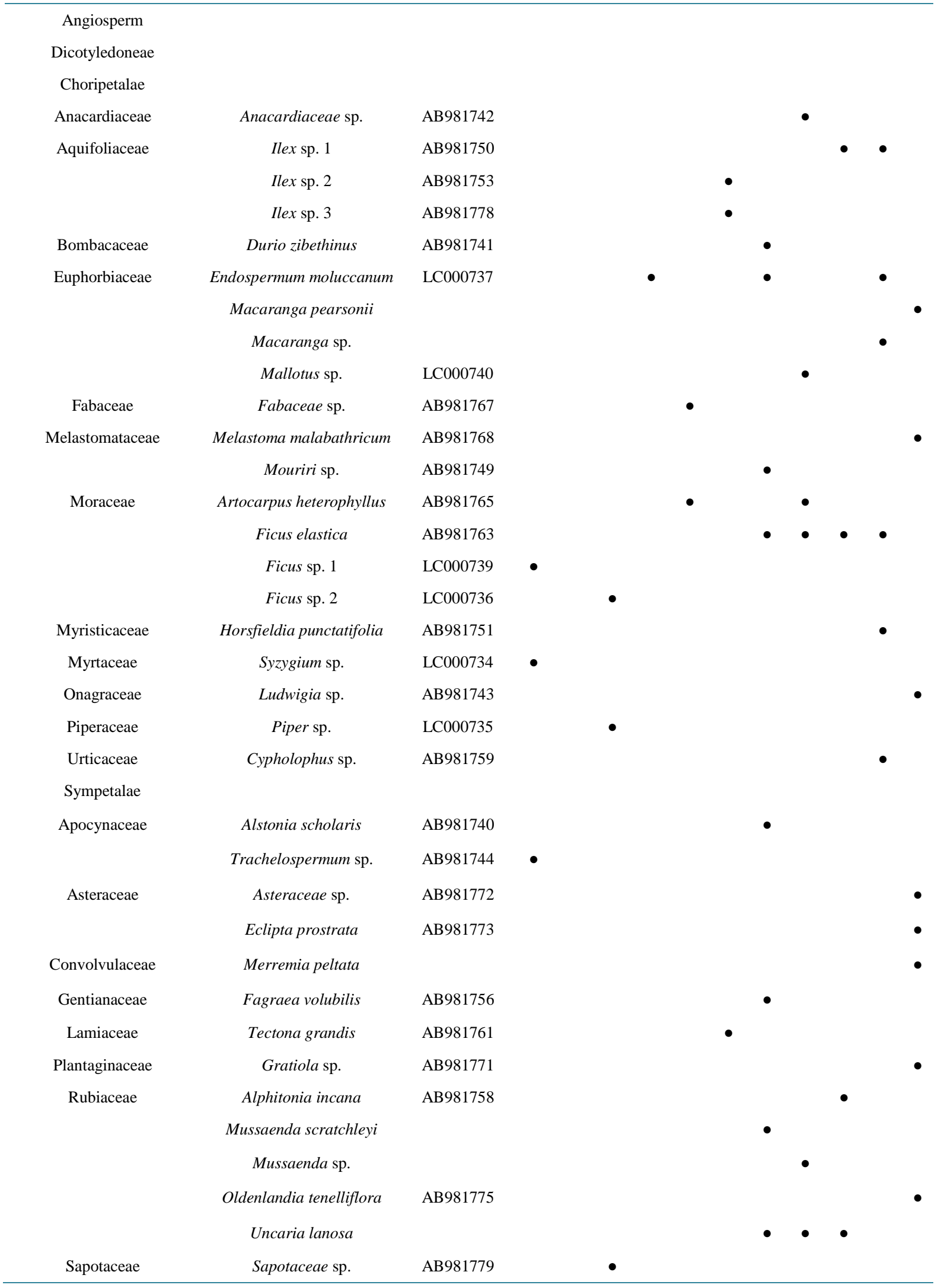


Table 2. The relative illumination intensity of each area in south Sorong distinct, West Papua province, Indonesia.

\begin{tabular}{ccccccccccccc}
\hline Quadrat Name & A1 & A2 & A3 & A4 & B1 & B2 & B3 & C & D1 & D2 & D3 \\
\hline Relative Illuminance (\%) & 0.74 & 1.31 & 0.99 & 0.66 & 74.15 & 8.00 & 1.55 & 92.77 & 42.66 & 8.24 & 1.18 \\
\hline
\end{tabular}

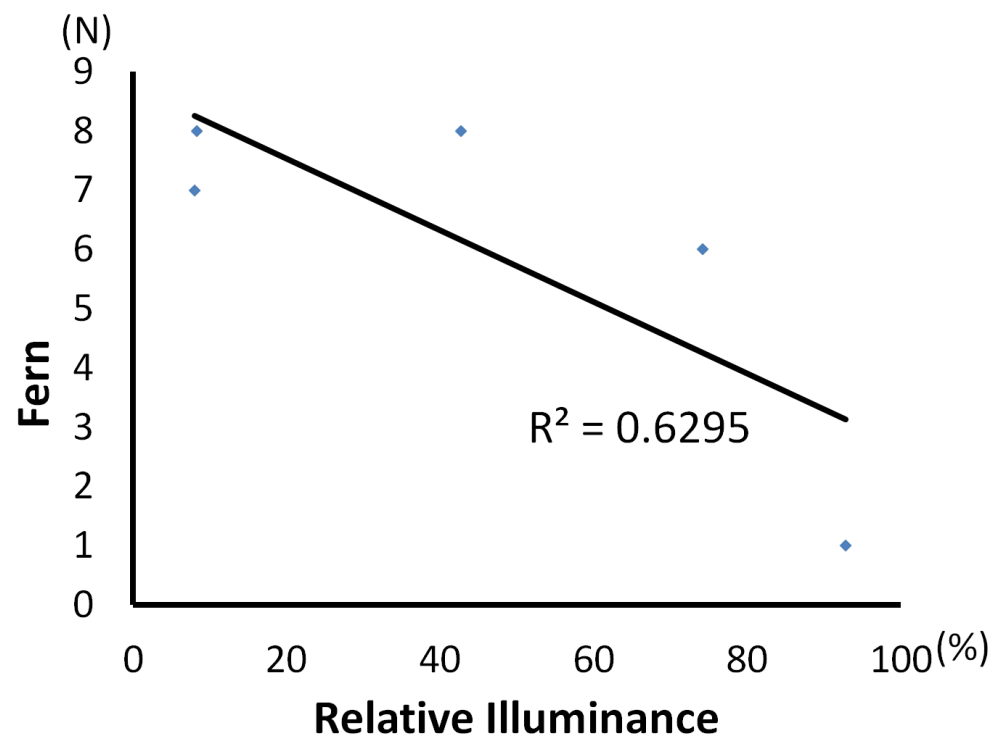

Figure 4. The correlation between the number of ferns and the relative illumination intensity.

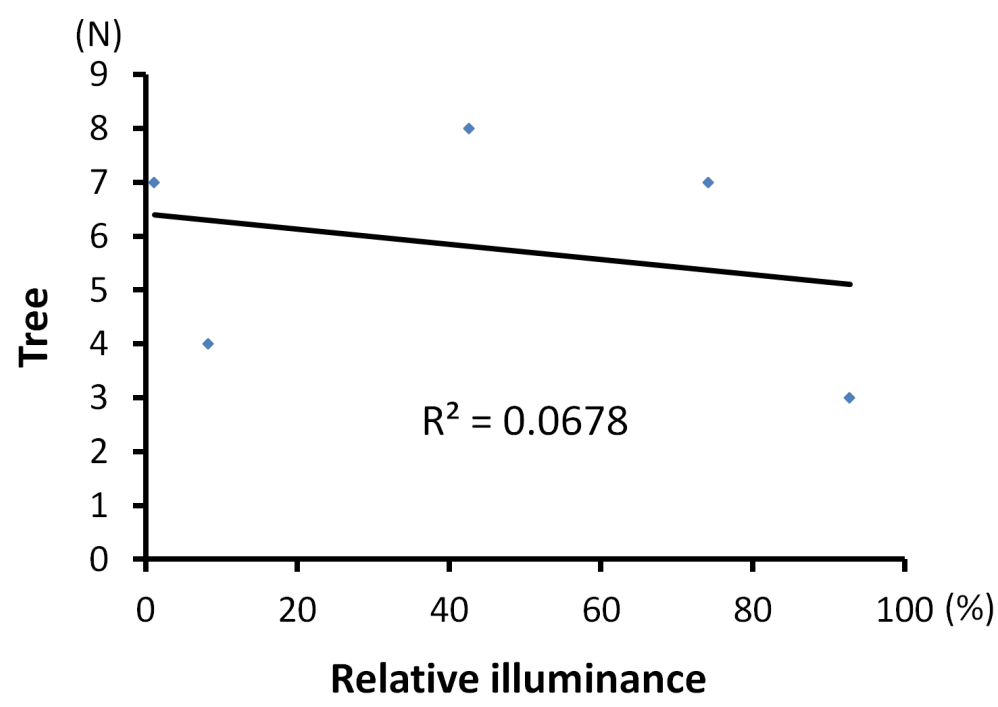

Figure 5. The correlation between the number of woody plant species and the relative illumination intensity.

in recent decades, these species have come to be regarded as important biological resources in need of conservation [31]. Although we consider that our genetic information of a given species in sago palm forests is thus an important research focus to design concerted efforts for their conservation, our research could not distinguish between native and alien plant species. Future analyses should include other areas to protect sago palm forests from genetic disturbance from invasive alien species.

\section{Acknowledgements}

This study was supported by a research grant from The Mitsui \& Co., Ltd. Environment Fund. 


\section{References}

[1] Watt, A.S. (1947) Pattern and Process in the Plant Community. Journal of Ecology, 35, 1-22. http://dx.doi.org/10.2307/2256497

[2] Hartshorn, G.S. (1978) Tree Falls and Tropical Forest Dynamics. In: Tomlinson, P.B. and Zimmermann, M.H., Eds., Tropical Trees as Living Systems, Cambridge University Press, Cambridge, 617-638.

[3] Brokaw, N.V.L. (1985) Gap-Phase Regeneration in a Tropical Forest. Ecology, 66, 682-687. http://dx.doi.org/10.2307/1940529

[4] Brokaw, N.V.L. (1987) Gap-Phase Regeneration of Three Pioneer Tree Species in a Tropical Forest. Journal of Ecology, 75, 9-19. http://dx.doi.org/10.2307/2260533

[5] Hubbell, S.P. and Foster, R.B. (1986) Biology, Chance and History and the Structure of Tropical Rain Forest Tree Communities. In: Diamond, J.M. and Case, T. J., Eds., Community Ecology, Harper and Row, New York, 314-329.

[6] Denslow, J.S. (1987) Tropical Rain Forest Gaps and Tree Species Diversity. Annual Review of Ecology and Systematics, 18, 431-451. http://dx.doi.org/10.1146/annurev.es.18.110187.002243

[7] Swaine, M.D., Lieberman, D. and Putz, F.E. (1987) The Dynamics of Tree Populations in Tropical Forest: A Review. Journal of Tropical Ecology, 3, 359-366. http://dx.doi.org/10.1017/S0266467400002339

[8] Martinez-Ramos, M., Alvarez-Buylla, E., Sarukhan, J. and Pinero, D. (1988) Treefall Age Determination and Gap Dynamics in a Tropical Forest. Journal of Ecology, 76, 700-716. http://dx.doi.org/10.2307/2260568

[9] Lawton, R.O. and Putz, F.E. (1988) Natural Disturbance and Gap-Phase Regeneration in a Wind-Exposed Tropical forest. Ecology, 69, 764-777. http://dx.doi.org/10.2307/1941025

[10] Uhl, C., Clark, K., Dezzeo, N. and Maquirino, P. (1988) Vegetation Dynamics in Amazonian Treefall Gaps. Ecology, 69, 751-763. http://dx.doi.org/10.2307/1941024

[11] Van der Meer, P.J. and Bongers, F. (1996) Patterns of Tree-Fall and Branch-Fall in a Tropical Rain Forest in French Guiana. Journal of Ecology, 84, 19-29. http://dx.doi.org/10.2307/2261696

[12] Yamamoto, Y., Yoshida, T., Miyazaki, A., Jong, F.S., Pasolon, Y.B. and Matanubun, H. (2005) Biodiversity and Productivity of Several Sago Palm Varieties in Indonesia. In: Karafir, Y.P., Jong, F.S. and Fere, V.E., Eds., Sago Palm Development and Utilization, Proceeding of the 8th International Sago Symposium, Jayapura, 4-6 August 2005, 35-40.

[13] Franklin, J.F., Shugart, H.H. and Harmon, M.E. (1987) Tree Death as an Ecological Process. BioScience, 37, 550-556. http://dx.doi.org/10.2307/1310665

[14] Kumekawa, Y., Murjoko, A., Hayakawa, H., Mori, M., Miyazaki, A., Ito, K., Arakawa, R., Fukuda, T., Matanubun, H. and Yamamoto, Y. (2014) Comparison of Species Composition between Different Light Condition of Sago Forest. Sago Palm, 22, 6-12.

[15] Hebert, P.D.N., Cywinska, A., Ball, S.L. and deWaard, J.R. (2003) Biological Identifications through DNA Barcodes. Proceedings of the Royal Society B: Biological Sciences, 270, 313-321. http://dx.doi.org/10.1098/rspb.2002.2218

[16] Kress, W.J., Wurdack, K.J., Zimmer, E.A., Weigt, L.A. and Janzen, D.H. (2005) Use of DNA Barcodes to Identify Flowering Plants. Proceedings of the National Academy of Sciences of the United States of America, 102, 8369-8374. http://dx.doi.org/10.1073/pnas.0503123102

[17] Hasebe, M., Omori, T., Nakazawa, M., Sano, T., Kato, M. and Iwatsuki, K. (1994) rbcL Gene Sequences Provide Evidence for the Evolutionary Lineages of Leptosporangiate Ferns. Proceedings of the National Academy of Sciences of the United States of America, 91, 5730-5734. http://dx.doi.org/10.1073/pnas.91.12.5730

[18] Taberlet, P., Gielly, L., Pautou, G. and Bouvet, J. (1991) Universal Primers for Amplification of Three Non-Coding Regions of Chloroplast DNA. Plant Molecular Biology, 17, 1105-1109. http://dx.doi.org/10.1007/BF00037152

[19] Thompson, J.D., Gibson, T.J., Plewniak, F., Jeanmougin, F. and Higgins, D.G. (1997) The CLUSTAL X Windows Interface: Flexible Strategies for Multiple Sequence Alignment Aided by Quality Analysis Tools. Nucleic Acids Research, 25, 4876-4882. http://dx.doi.org/10.1093/nar/25.24.4876

[20] Koch, H. (2010) Combining Morphology and DNA Barcoding Resolves the Taxonomy of Western Malagasy Liotrigona Moure, 1961 (Hymenoptera: Apidae: Meliponini). African Invertebrates, 51, 413-421. http://dx.doi.org/10.5733/afin.051.0210

[21] Fukuda, T., Song, I.J., Nakamura, T., Nakada, M., Kanno, A., Kameya, T., Yamaji, H., Terabayashi, A., Takeda, S., Aburada, M. and Yokoyama, J. (2005) Molecular Identification of Tiandong Derived from Asparagus cochinchinensis (Lour.) Merrill by Two Typical Deletions in cpDNA. Natural Medicines, 59, 91-94.

[22] Hayakawa, H., Kobayashi, T., Minamiya, Y., Ito, K., Miyazaki, A., Fukuda, T. and Yamamoto, Y. (2010) Molecular Identification of Turmeric (Curcuma longa, Zingiberceae) with a High Curcumin Content. Journal of Japanese Botany, 85, 263-269. 
[23] Hayakawa, H., Kobayashi, T., Minamiya, Y., Ito, K., Miyazaki, A., Fukuda, T. and Yamamoto, Y. (2011) Development of a Molecular Marker to Identify a Candidate Line of Turmeric (Curcuma longa L.) with a High Curcumin Content. American Journal of Plant Sciences, 2, 15-26. http://dx.doi.org/10.4236/ajps.2011.21002

[24] Kumekawa, Y., Murjoko, A., Hayakawa, H., Ohga, K., Mori, M., Miyazaki, A., Ito, K., Arakawa, R., Fukuda, T., Matanubun, H. and Yamamoto, Y. (2013) Molecular Analyses of Folk Varieties of the Sago Palm (Metroxylon sagu Rottb) Using the Internal Transcribed Spacer (ITS) Region and Nuclear Microsatellite DNA. Sago Palm, 21, 14-19.

[25] Gilliam, F.S. (2007) The Ecological Significance of the Herbaceous Layer in Temperate Forest Ecosystems. Bioscience, 57, 845-858. http://dx.doi.org/10.1641/B571007

[26] Yamamoto, S. (2000) Forest Gap Dynamics and Tree Regeneration. Journal of Forest Research, 5, $223-229$. http://dx.doi.org/10.1007/BF02767114

[27] Nishiyama, Y. and Abe, T. (2003) Estimation of Biomass and Vegetation Coverage of Understories in Old Chamaecyparis obtusa Plantations. The Society of Applied Forest Science, 12, 151-157.

[28] Avise, J.C., Arnold, J., Ball, R.M., Bermingham, E., Lamb, T., Neigel, J.E., Reeb, C.A. and Saunders, N.C. (1987) Intraspecific Phylogeography: The Mitochondrial DNA Bridge between Population Genetics and Systematics. Annual Review of Ecology and Systematics, 18, 489-552.

[29] Schaal, B.A. and Olsen, K.M. (1999) Gene Genealogies and Population Variation in Plants. Proceedings of the National Academy of Sciences of the United States of America, 97, 7024-7029. http://dx.doi.org/10.1073/pnas.97.13.7024

[30] Harter, A.V., Gardner, K.A., Falush, D., Lentz, D.L., Bye, R.A. and Rieseberg, L.H. (2004) Origin of Extant Domesticated Sunflowers in Eastern North America. Nature, 430, 201-205. http://dx.doi.org/10.1038/nature02710

[31] Tanksley, S.D. and McCouch, S.R. (1997) Seed Banks and Molecular Maps: Unlocking Genetic Potential from the Wild. Science, 277, 1063-1066. http://dx.doi.org/10.1126/science.277.5329.1063 
Scientific Research Publishing (SCIRP) is one of the largest Open Access journal publishers. It is currently publishing more than 200 open access, online, peer-reviewed journals covering a wide range of academic disciplines. SCIRP serves the worldwide academic communities and contributes to the progress and application of science with its publication.

Other selected journals from SCIRP are listed as below. Submit your manuscript to us via either submit@scirp.org or Online Submission Portal.
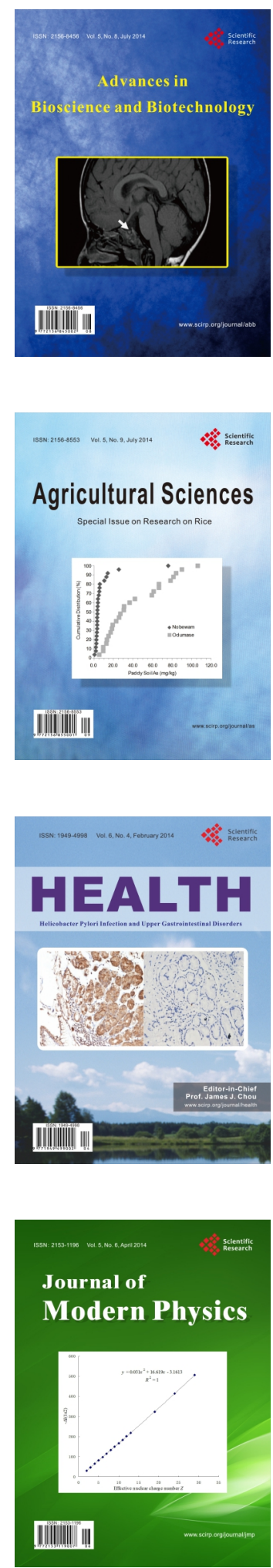
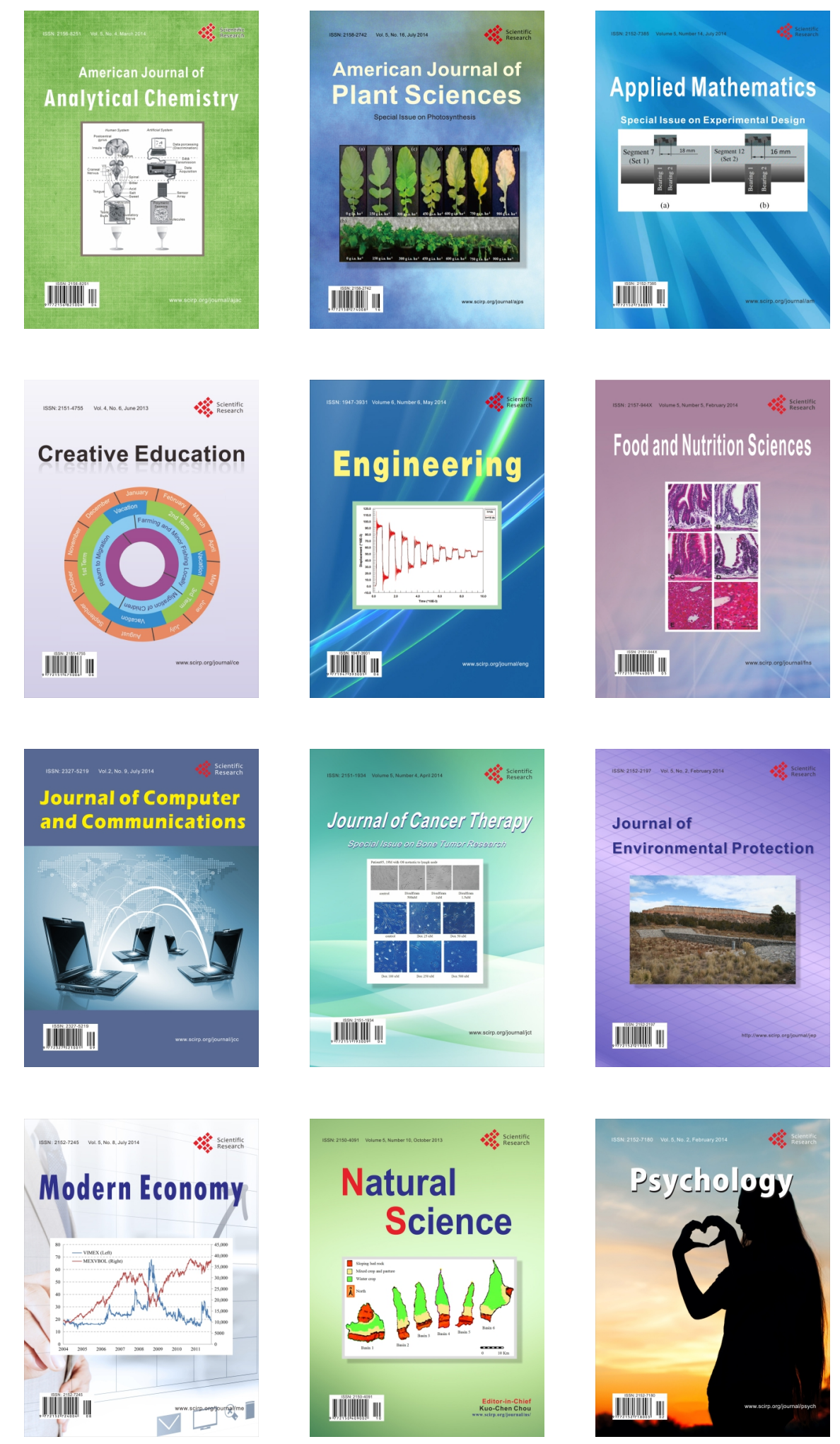